\title{
$\mathrm{LCD}$ 램프홀더용 실리콘고무재료의 후가교 조건
}

안원술 ${ }^{*}$, 이준만 ${ }^{1}$

${ }^{1}$ 계명대학교 화학공학과

\section{Post-cure Condition of a Silicone Rubber Material for a LCD Lamp Holder}

\author{
Won-Sool $\mathrm{Ahn}^{1^{*}}$ and Joon-Man Lee ${ }^{1}$ \\ ${ }^{1}$ Department of Chemical Engineering, Keimyung University, Daegu 704-701, Korea
}

\begin{abstract}
요 약 TGA 열분석법을 이용하여 LCD 백라이트 램프 홀더용으로 사용되는 실리콘 고무성형품샘플에 대하여 서로 다른 몇 가지 온도에서의 등온 후가교 특성을 연구하였다. 특히 실제 사용 환경에서의 내열조건과 관련된 후가교 특 성 및 적정 후가교 조건에 대하여 촛점을 맞추어 연구하였고 시간-온도중첩원리를 응용하는 촉진 실험법의 적용 가능 성을 알아보았다. LCD 램프홀더용의 실리콘 재료의 실제 사용 환경을 고려할 때, 휘발성 물질의 배출에 의한 중량감 소가 처음 시작되는 온도인 $\mathrm{T}_{\mathrm{i}}$ 가 가장 중요한 고려 요인이며, 이를 고려하여 도출되는 후가교 조건은 $250^{\circ} \mathrm{C}, 2$ 시간이 적절한 것으로 생각되었다. 시간-온도 중첩원리와 실험적으로 결정된 이동인자는 Arrhenius식을 잘 만족함을 보여 주 었으며 이로부터 후가교과정은 활성화에너지 $108.25 \mathrm{~kJ} / \mathrm{mol}$ 의 값을 가지는 단일 메커니즘으로 진행됨을 알 수 있었다.
\end{abstract}

\begin{abstract}
Post-cure characteristics of a silicone rubber material which is widely used for a LCD lamp holder were investigated using thermogravimetric analysis (TGA). Research was especially focussed on searching for the optimum post-cure conditions in relation to the practical operation environments. The results showed that incipient volatile temperature( $\mathrm{Ti}$ ) during the process was considered as the most important factor and, thereby, post-curing for $2 \mathrm{hrs}$ at $250^{\circ} \mathrm{C}$ seemed to be a reasonable condition in the practical view-point. Arrhenius plot of shift factors which were empirically determined from the time-temperature-superposition-principle showed good linearity, exhibiting the post-cure mechanism might be proceeded through single mechanism with activation energy of $108.25 \mathrm{~kJ} / \mathrm{mol}$.
\end{abstract}

Key Words : Silicone rubber, LCD, Post-cure, TGA, TTSP

1. 서론

실리콘 고무는 일반적인 유기고분자와는 달리 고분자 주쇄가 실리콘과 산소원자의 연결쇄 (-Si-O-)로 이루어진 특수한 고분자이기 때문에 여타의 고무와는 달리 고온 및 특성, 내열성, 전기절연성, 내약품성, 발수성, 계면특 성 등의 여러 가지 물리화학적 특성이 뛰어난 고분자로 서 고온 내열환경에 대한 내구성이 요구되는 전선 피복 용으로나 전자기기의 부품용, $\mathrm{LCD}($ Liquid Crystal Display)의 백라이트 램프홀더용 등으로 활용분야가 넓 다. 또한 냄새가 없고 인체에 무해하며 무색투명하기 때
문에 가스 마스크나 수술용 튜브의 제조 등 산업의 여러 분야에 걸쳐 골고루 많이 쓰이고 있다[1-5].

상업적으로 시판되고 있는 일반적인 실리콘 생고무 (polydimethyl siloxane, PDMS) 원료는 - $\left[\left(\mathrm{H}_{3} \mathrm{C}\right)_{2} \mathrm{SiO}\right]_{\mathrm{m}}-\left[\left(\mathrm{CH}_{3} \mathrm{CHCH}_{2}\right) \mathrm{SiO}\right]_{\mathrm{n}}$-의 반복단위를 가지는 메칠비닐(methyl vinyl)계이며, siloxane 반복단위의 수에 따라 $3,000 \sim 10,000$ 까지의 고점도형(high-consistency), 50 2,000까지의 상온경화형(Room Temperature Vulcanizing, RTV), 및 200 1,500까지의 액상 실리콘 고 무(Liquid Silicone Rubber, LSR)의 크게 3가지로 나뉜다. 이 중에서도 $\mathrm{LSR}$ 은 일반적으로 RTV 고무로 불리기도

본 연구는 지식경제부-한국산업기술평가원 지정 계명대학교 저공해자동차부품기술개발센터의 지원임.

"교신저자 : 안원술(wahn@kmu.ac.kr)

접수일 09 년 06 월 12 일 수정일 09 년 07 월 10 일

게재확정일 09년 07월 22일 
했으나 현재는 고온 경화형 액상 원료고무도 많으므로 $\mathrm{LSR}$ 은 좀 더 포괄적인 열경화형 실리콘 고무를 지칭한다 [4].

TV나 노트북 등의 전자기기의 디스플레이로 가장 많 이 사용되고 있는 $\mathrm{LCD}$ 는 백라이트 램프를 광원으로 사 용하는데 전극 부위는 실리콘 고무로 된 램프 홀더에 의 하여 밀폐되어 있다. 또한 램프를 포함한 부품들은 매우 콤팩트하게 구성되어 있으므로 사용 시의 전극부위는 일 시적으로 $150^{\circ} \mathrm{C}$ 이상의 고온으로 상승하는 경우가 있으 므로 전자부품의 보호를 위하여 램프 홀더 재료는 고압 축성, 내충격성과 함께 고온 내열환경에 내구성을 가지는 고무재료를 사용하여야 한다. 이러한 요구 특성을 만족하 는 재료로서 실리콘 고무는 가장 적절한 부품 재료로 활 용되고 있다[4,8]. 특히, LCD 백라이트 램프는 고투명성 의poly methylmethacrylate (PMMA)로 만들어진 도광판 과 직접 접촉하게 되므로, 실리콘 램프 홀더의 제조과정 에서 생겨난 저분자 화합물(Low molecular weight compounds, LMWCs)이 외부로 스며 나올 경우 PMMA 투명 도광판 면의 부식이나 오염 등에 의한 얼룩점을 발 생시키게 되어 제품의 불량을 유발하게 되는 주요 원인 이 된다. 따라서 이러한 특수용도의 경우에는 분해 과산 화물이 많이 생기는 라디칼반응보다는 백금화합물을 사 용하는 부가반응에 의해 1 차가교 반응을 거치고 다시 2 차의 후가교(post-cure) 반응에 의하여 제품 내의 잔존물 을 제거하여 제품의 물리화학적인 안정성을 꾀하게 된다[3].

한편 2차 후가교의 경우 일반적으로는 $200^{\circ} \mathrm{C}$ 정도의 온도에서 1 4시간 정도에 그치고 있는 데 이에 대한 합 리적인 설명이나 후가교의 적정 온도 및 적정 시간에 대 한 정보는 매우 부족한 실정이며, 열중량분석법 (thermogravimetric Analysis, TGA)와 같은 정밀한 열분석 기기를 사용하여 연구를 체계적으로 진행한 결과도 적다. 더욱이 실리콘 후가교는 실질적인 제품의 사용용도에 따 라 후가교하는 조건이 매우 달라서 경우에 따라서는 같 은 온도에서도 수 십 시간을 더 처리해야하는 경우도 있 다. 따라서 본 연구에서는 특히 현재 상업용의 LCD 램프 홀더용 재료로 사용되고 있는 실리콘 고무에 한정하여, $\mathrm{TGA}$ 를 이용한 후가교 조건에 따른 재료의 열적 특성 변 화를 실험실 규모에서 연구하고 이 결과를 상업화된 제 품의 품질관리시스템과 연계하여 응용할 수 있는 방법에 대하여 집중적으로 살펴보았다.

\section{2. 실험}

\section{1 실험재료 및 샘플제조}

$\mathrm{LCD}$ 램프홀더에 사용되는 실리콘 고무의 원료는 국 내 (주)HRS에서 생산되는 액상의 polydimethyl siloxane(PDMS)계 실리콘 생고무 원료를 사용하고 충전 제로서 표면처리된 Fumed silica를 사용하였다. 또한 충 전제와 PDMS와의 계면접착력을 향상시키기 위하여 silanol 처리된 저분자량의 액상 PDMS를 가공조제와 함 께 사용하였다. 표 1 에 본 연구에 사용된 실리콘 고무 샘 플의 재료와 조성비를 나타내었다.

[표 1] LCD 램프홀더용 재료 조성

\begin{tabular}{c|c|c|c}
\hline $\begin{array}{c}\text { 순 } \\
\text { 서 }\end{array}$ & 실험재료 & Cas No. & wt\% \\
\hline \hline 1 & $\begin{array}{c}\text { Polydimethyl Siloxane } \\
\text { (PDMS) }\end{array}$ & $9016-00-6$ & 50.0 \\
\hline 2 & Fumed Silica & $112945-52-5$ & 43.0 \\
\hline 3 & $\begin{array}{c}\text { Polydimethyl Siloxane Oil } \\
\text { (Silanol-terminated PDMS) }\end{array}$ & $70131-67-8$ & 6.0 \\
\hline 4 & 가공조제 & & 1.0 \\
\hline
\end{tabular}

그림 1에 보이는 형상을 가진 LCD 램프홀더는 압축성 형에 의하여 만들어진다. 본 실험에서 사용된 실리콘 샘 플은 (주)창성정밀의 압축성형기를 사용하여 금형 상부 온도와 하부온도 각각 150 및 $145^{\circ} \mathrm{C}$, 압력 $110 \pm 10 \mathrm{~kg}_{f} / \mathrm{cm}^{2}$ 및 가교시간 $120 \mathrm{sec}$ 의 1 차 가교성형조건으로 만들어 내 었다. 2 차 후가교는 반응기에 샘플을 넣은 다음에 온도 $130 \pm 10^{\circ} \mathrm{C}$ 에서 30 분 정도 예열한 후에 다시 $250 \pm 10{ }^{\circ} \mathrm{C}$ 로 승온시킨 상태에서 강제 배기시키면서 각각 3 시간, 4 시 간 동안 유지하여 만들었다.

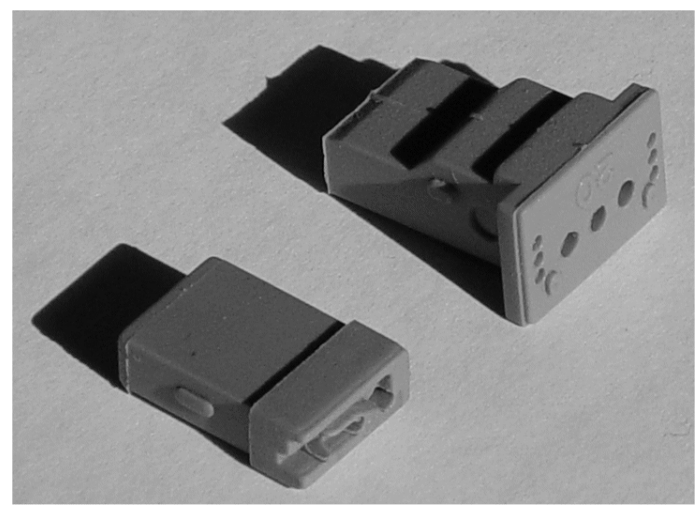

[그림 1] 실리콘고무로 만들어진 $\mathrm{LCD}$ 램프홀더

\subsection{TGA열분석 및 데이터 해석}

후가교 공정까지 마친 재료는 Shimazu TGA-50 열중 
량분석기 (Thermo-Gravimetric Analyzer, TGA)를 이용하 여 상온에서부터 $800^{\circ} \mathrm{C}$ 까지 $20^{\circ} \mathrm{C} / \mathrm{min}$ 의 승온 속도로 온 도를 올리며 실험하여 각각의 시료에 대한 $\mathrm{TGA}$ thermogram을 얻었다. 본 연구에서의 경우에는 시료의 감량이 시작되는 온도가 중요하므로 얻어진 열분석 곡선 으로부터 DTG등의 분석방법을 이용하여 초기무게감량 이 시작되는 온도 $\left(\mathrm{T}_{\mathrm{i}}\right)$ 를 알아내었다. 한편 1차 가교 과정 만 거친 샘플은 $200,220,250$, 및 $280^{\circ} \mathrm{C}$ 의 서로 다른 온 도에서의 공기분위기 하에서 시간에 따른 무게 감량 곡 선을 얻었다. 또한 강제배기 조건에서의 무게 감량 특성 을 살펴보기 위하여 공기흐름 및 정지 상태에서의 등온 TGA 실험을 따로 행하였다. 시료 샘플의 무게는 약 $15 \mathrm{mg}$ 되도록 정량하여 사용하였다. 서로 다른 온도에서 얻은 곡선들은 시간-온도중첩원리(Time-Temperature Superposition Principle, TTSP)를 이용하여 실험적으로 이동인자를 구하고 이로부터 $200^{\circ} \mathrm{C}$ 기준온도에서의 마스 터곡선을 작성하였다.

\section{3. 결과 및 고찰}

실리콘 고무는 앞에서 살펴본 데로 실리콘 생고무에 실리카 등의 보강용 충전제와 가소제를 혼련하여 만든 base polymer에 다시 증량제와 첨가제를 혼입하고, 여기 에 가교제와 착색제를 섞은 뒤에 가열 성형하게 된다. 또한 대부분의 실리콘계 고무 성형품은 1 차 가교 반응 후 에 다시 2차 후가교 반응을 행하게 되는데 이의 주목적은 원재료 속에 남아 있는 가교제의 분해 잔류물의 제거와 성형품의 사용온도 이상의 열 이력을 부여하여 사용 온 도에서의 열적 안정성을 꾀하고자 하는 데에 있다. 대개 의 LSR을 사용하는 산업용 실리콘 제품의 경우 1 차가교 반응은 $150^{\circ} \mathrm{C}$ 전후의 온도와 몰드압력 하에서 2 3분 정 도에 끝나게 되며 2차 후가교반응은 $200^{\circ} \mathrm{C}$ 정도에서 1 4 시간 정도 강제 환기하면서 행하게 된다[3].

2차 후가교 과정에서 배출되는 휘발성가스 상의 물질 은 크게 저분자량의 실리콘화합물인 LMWS와 1차가교 반응 시에 사용되는 개시제 부산물의 두 가지로 분류된 다. LMWS은 미반응된 저분자 원료물질이나 열에 의한 해중합이나 열화에 의한 저분자화합물들이 주류를 이루 고 개시제부산물은 퍼옥사이드에 의한 벤조산 등의 부산 물이다[8]. 실제로 LCD 램프 홀더가 사용되는 램프의 전 극부위는 전극과 외부전선의 접점을 중심으로 열수축튜 브와 전선의 피복 플라스틱 등이 함께 밀봉되어 있는 구 조이므로 전극 부위에서 일시적인 과열현상이 발생하면 이들 저분자화합물 들은 휘발에 의하여 외부로 누출되어
전기부품의 손상을 유발하거나 PMMA 도광판에 응축 침 착됨으로서 얼룩점 등을 만들게 되므로 제품 불량의 근 원이 될 수 있다.

그림 2 에서는 $250^{\circ} \mathrm{C}$ 에서 3 시간 및 4시간 동안 공기를 순환시키면서 후가교를 거친 샘플의 TGA thermogram을 나타낸다. 그림 2에서 보아 잘 알 수 있듯이 두 가지 시료 샘플의 중량감소가 처음 시작되는 온도 $\mathrm{T}_{\mathrm{i}}$ 는 모두 약 $320^{\circ} \mathrm{C}$ 부근이며 이후에는 450 과 $550^{\circ} \mathrm{C}$ 를 중심으로 전형 적인 실리콘 고무의 열분해 특성을 보이고 있다. 한편 $\mathrm{T}_{\mathrm{i}}$ 는 앞에서 기술한 램프홀더 부위의 예상 최고 온도인 $150^{\circ} \mathrm{C}$ 보다 훨씬 높기 때문에 보통의 일반적인 사용 조 건에서의 시간에 따른 휘발성 물질의 배출량은 매우 미 미할 것으로 생각된다. 또한 3 시간 및 4시간을 각각 후가 교 시킨 것의 $\mathrm{T}_{\mathrm{i}}$ 값은 서로 크게 다르지 않은 값을 보이며 이러한 사실은 실제 생산현장에서는 제품의 생산원가에 영향을 미치는 경제성의 요인으로서 어떤 온도에서 얼마 동안 후가교를 시켜야 가장 적절할 것인가 하는 문제로 직결된다.

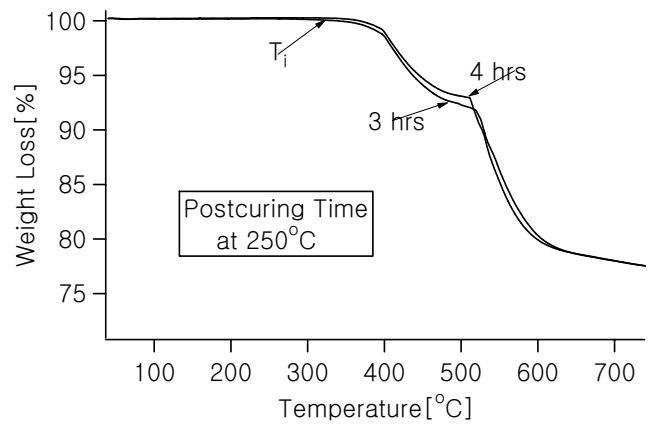

[그림 2] $250^{\circ} \mathrm{C}$ 에서 3 시간 및 4 시간 후가교를 거친 샘플의 $\mathrm{TGA}$ 곡선. $\mathrm{T}_{\mathrm{i}}$ 는 초기휘발시작점 온도

과산화물로 가교된 범용 실리콘 고무의 경우 1 차 가교 후에 $200^{\circ} \mathrm{C}$ 에서 4 시간 정도 등온 TGA 실험을 진행하면 대개 2.5 4.0\%정도의 무게 감량이 생기는데 이는 1차 가교 후에 생겨나는 저분자 화합물 들의 상당량이 제품 내에 잔존하고 있음을 나타낸다[3]. 그러나 본 연구에서 와 같이 전자부품에 사용되는 실리콘 고무는 백금 촉매 를 사용하므로 위에서와 같이 많은 양의 생성 부산물은 잔존하지 않는다. 그럼에도 불구하고 $\mathrm{LCD}$ 램프홀더로 사용되는 실리콘 고무는 상대적으로 밀폐된 상황에서 고 온에서 열화되기 쉬운 열수축 튜브나 전선 피복물 등의 다른 고분자와 함께 사용되고 있기 때문에 반복적으로 고온에 노출될 경우 내부에 잔류하는 저분자화합물의 휘 발 및 응축에 의해 제품 불량을 유발시킬 수 있다. 따라 
서 제품 내에 잔존하는 저분자 화합물의 양을 최대한 줄 이는 것이 불량률을 줄이는 관건이라 할 것이다.

그림 3 에서는 1 차가교만 시킨 샘플재료를 사용하여 $250^{\circ} \mathrm{C}$ 의 온도에서 공기흐름 및 정지 상태에서의 시간에 따른 등온 TGA 곡선을 나타내고 있다. 그림에서 보듯이 초기의 급격한 중량 감소 후에 공기흐름이 없는 조건에 서는 감소량이 상대적으로 더 적음을 알 수 있다. 이는 샘플로부터의 휘발성물질이 빠져나오는 것이 원활하지 않음을 나타낸다. 본 실험에서의 경우에는 $15 \mathrm{mg}$ 정도의 미량 시험 샘플 량에 비하여 TGA 샘플홀더를 포함한 주 위의 공간이 상대적으로 매우 크기 때문에 두 경우에 크 게 차이가 나지 않으나, 실제 공정에서의 경우에는 후가 교 반응기의 내부 공간에 비하여 재료의 부피가 상대적 으로 매우 크므로 공기흐름 즉, 강제 환기 조건은 매우 중요하다. 왜냐하면 환기가 이루어지지않는 상태에서 후 가교가 진행되면 휘발되는 유기물들이 실리콘 고무 제품 내에 계속 갇혀 있게 되고 이는 역으로 재료의 해중합에 의한 재료의 열화를 촉진시킬 수 있기 때문이다 $[9,10]$.

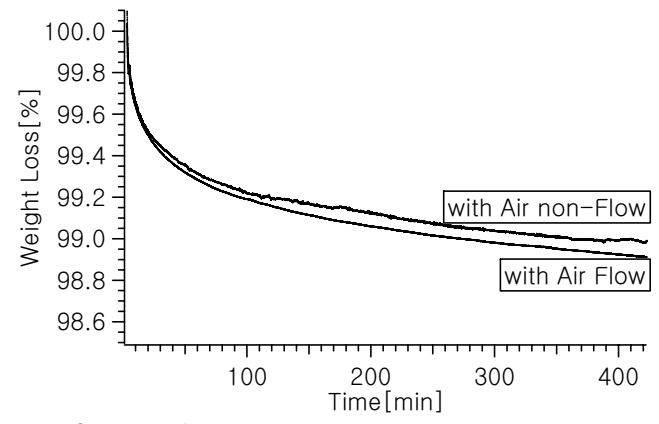

[그림 3] $250^{\circ} \mathrm{C}$ 등온 후가교 시의 강제 환기 및 환기정지 조건에 따른 TGA 곡선

그림 4는 1 차가교만 시킨 샘플을 사용하여 200,220 , 250 , 및 $280^{\circ} \mathrm{C}$ 의 서로 다른 각각의 온도에서 공기 분위기 에서 시간에 따른 무게 감량 변화를 실험한 TGA thermogram들이다. 실험 시작 시에 정해진 온도까지는 약 $100^{\circ} \mathrm{C} / \mathrm{min}$ 정도의 빠른 속도로 승온시킨 후에 시간에 따른 무게 감량을 측정하였다. 이 그림으로부터 살펴볼 때 몇 가지 특징적인 것을 알아낼 수 있다. 첫 째로는 정 해진 각각의 온도에서 시간에 따른 샘플의 무게 감소현 상은 지수적이며 또한 후가교시의 초기에는 약 20 30분 에 걸쳐 급격한 중량 감소가 일어나며 그 이 후에는 서서 히 감소하는 이중모드로 진행된다는 사실이다. 이러한 사 실은 후가교 시의 초기에는 1 차가교 된 재료의 내부에 잔 류하는 미반응 LMWS 및 개시제의 부반응에 의한 저분 자량 화합물의 휘발 현상이 우세하며 그 이후에는 추가
적으로 일어나는 샘플내부로 부터의 확산에 의한 잔존화 합물의 휘발과 고분자의 해중합에 의해 생성되는 고리형 저분자량 실리콘 화합물 등의 휘발에 기인하는 것으로 해석할 수 있다.

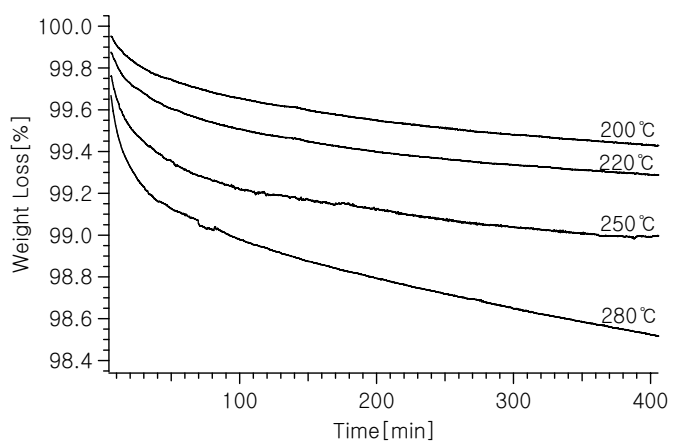

[그림 4] $200,220,250$, 및 $280^{\circ} \mathrm{C}$ 의 서로 다른 온도에서 후가교 시킬 때의 시간에 따른 등온 TGA 곡선

두 번째의 특징적인 사실로서는 초기의 급격한 무게 감소 이후에는 시간에 따른 무게의 감소율이 각각의 온 도에서 모두 약 $0.034 \mathrm{wt} \% / \mathrm{hr}$ 로서 거의 일정함을 알 수 있다. 이것은 1 차반응에서 생성된 휘발성 저분자화합물 들이 초기에 거의 모두 휘발하고 나면 확산 및 추가로 생 성되는 저분자 화합물들의 양은 매우 미미한 것임을 알 수 있게 한다. 그러나 $280^{\circ} \mathrm{C}$ 의 경우에는 $0.086 \mathrm{wt} \% / \mathrm{hr}$ 으 로서 2 배 이상 더 큰 감소율을 보이는 데, 이는 지나치게 높은 후가교 온도의 설정으로 인하여 초기의 급격한 무 게 감소 이후에도 열화에 의한 저분자량화합물의 생성이 많아진다는 것을 의미한다. 따라서 본 연구에서의 실리콘 샘플에 대한 후가교의 적정온도는 $250^{\circ} \mathrm{C}$ 정도가 한계 온 도일 것으로 판단할 수 있다.

한편 이러한 이중 모드의 무게 감소현상은 그림 5 의 $250^{\circ} \mathrm{C}$ 의 thermogram에 대한 예에서 보이는 바와 같이 각 각의 thermogram에 대하여 이중모드 지수함수로 curve fitting할 경우 거의 실험치와 유사하게 fitting할 수 있음 을 알 수 있다. 각각의 후가교 온도에 대하여 이러한 과 정을 반복하여 fitting parameter를 계산하였고 이를표 2 에 정리하여 나타내었다. 따라서 각각 온도에서의 fitting parameter를 사용하면 각 온도에서의 장시간에 걸친 샘플 의 무게 감량은 주어진 계수 값을 가지는 이중모드 지수 함수로 예측할 수 있다. 수식 중에서 초기의 fast-motion 에 해당하는 $\tau_{1}$ 이 $20 \mathrm{~min}$ 전후이며 이 후의 slow-motion 에 해당하는 값은 약 $230 \pm 15 \mathrm{~min}$ 임을 알 수 있고 이것은 초기 20 분 전후의 급격한 중량감소 이후 4 시간 정도 지 나면 샘플이 거의 안정화 된다는 것을 의미한다. 그러나 
이후에도 샘플의 중량 감소는 느리지만 계속하여 진행되 고 이로부터 각 온도에서의 최대 무게 감량도 후가교 온 도가 높을수록 커지며 $250^{\circ} \mathrm{C}$ 의 경우 약 $1.13 \mathrm{wt} \%$ 가 됨을 알 수 있다.

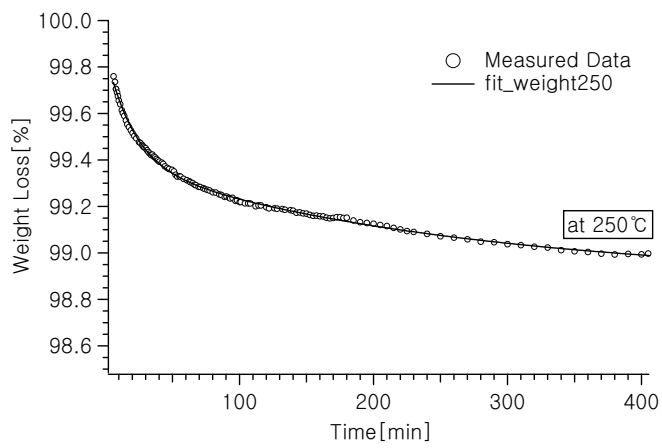

[그림 5] $250^{\circ} \mathrm{C}$ 등온 후가교 샘플의 TGA 곡선에 대하여 수식 $w=w_{0}+k_{1} e^{-t / \tau_{1}}+k_{2} e^{-t / \tau_{2}}$ 에 의한 이 중모드 Arrhenius 플롯

[표 2] 이중모드 Arrhenius 플롯에서의 후가교 온도와 curve-fitting parameter

\begin{tabular}{c|c|c|c|c|c|c}
\hline \multirow{2}{*}{$\begin{array}{c}\text { Post-cure } \\
\text { temperature } \\
{\left[{ }^{\circ} \mathrm{C}\right]}\end{array}$} & \multicolumn{6}{|c}{$w=w_{0}+k_{1} e^{-t / \tau_{1}}+k_{2} e^{-t / \tau_{2}}$} \\
\cline { 2 - 7 } & $w_{0}$ & $k_{1}$ & $\tau_{1}$ & $k_{2}$ & $\tau_{2}$ & $\tau_{2} / \tau_{1}$ \\
\hline \hline 200 & 99.30 & 0.20 & 19.13 & 0.48 & 253.52 & 13.25 \\
\hline 220 & 99.20 & 0.26 & 19.90 & 0.46 & 216.03 & 10.86 \\
\hline 250 & 98.87 & 0.47 & 20.17 & 0.51 & 250.38 & 12.81 \\
\hline 280 & 98.11 & 0.62 & 14.78 & 1.12 & 411.37 & 27.83 \\
\hline
\end{tabular}

한편 후가교의 적정온도와 시간은 제품의 사용분야 및 재료특성과 관련되어 각각의 제품마다 일정하지 않다. 본 연구에서 사용된 $\mathrm{LCD}$ 램프홀더 재료의 경우, $250^{\circ} \mathrm{C}$ 에서 2 시간 정도의 2 차 후가교반응을 행하여 완제품으로 사용 하는 데 현재까지 이 조건은 사용 환경에서의 제품불량 을 일으키지 않는 후가교 조건으로 알려져 있다[10]. 가 장 중요하게 생각되는 안정성 판단 요인으로는 사용온도 에서의 휘발성 물질의 양이며 실제로 그림 5 에서 계산되 는 fitting parameter들을 이용하여 $250^{\circ} \mathrm{C}$ 에서 후가교 시 간을 한 시간 씩 더 증가시킬 때마다의 무게 감량율을 계 산해보면 2 시간 후에는 $0.80 \%$ 의 무게감량이 생기고 그 이 후에는 $0.034 \% / \mathrm{hr}$ 정도로 서서히 감량이 일어난다. 따 라서 본 연구에서 사용된 샘플의 경우, 적정 후가교의 조 건을 위한 판단인자로는 샘플의 무게 감량으로 택할 수 있고, 정량적으로는 $0.80 \%$ 의 무게감량이 일어나는 온도 및 시간으로 책정하는 것이 적절한 후가교 조건으로 생
각된다. 즉, 이 조건으로 후가교 과정을 거친 $\mathrm{LCD}$ 램프 홀더용의 실리콘제품은 $150^{\circ} \mathrm{C}$ 정도의 일시적인 온도 상 승을 포함하는 실제의 낮은 동작온도에서는 사용시간 동 안 발생하는 휘발물질들의 양이 극히 미량에 불과하고 따라서 이로 인한 불량은 유발되지 않을 것으로 생각된 다. 그러나 $250^{\circ} \mathrm{C}$ 에서 보다 더 낮은 온도에서의 후가교처 리에는 횔씬 더 오랜 시간이 걸릴 수 있다. 즉, 표 2 에서 보듯이 $220^{\circ} \mathrm{C}$ 에서는 최종적으로 $0.8 \mathrm{wt} \%$ 의 무게 감량에 이르지만 $200^{\circ} \mathrm{C}$ 의 후가교 온도에서는 후가교시간을 매우 오래 하더라도 거의 $0.8 \mathrm{wt} \%$ 에 이르지 못한다는 사실을 알 수 있다. 따라서 본 연구에서의 실리콘 재료 샘플의 경우 적정 후가교 온도로서 $220 \sim 250^{\circ} \mathrm{C}$ 의 범위로 정하는 것이 합리적인 것이라고 생각할 수 있다.

고무제품의 사용온도에서의 수명을 측정하는 일은 보 통의 경우 제품 수명이 매우 길기 때문에 실시간 측정이 힘 든 경우가 많다. 따라서 고분자 제품의 경우에는 고온 촉진 실험에 의하여 수명을 예측하게 되는데 여기에는 시간-온도 중첩원리 (Time-Temperature Superposition Principle, TTSP)가 이용된다. TTSP의 기본적인 원리는 '고온에서의 짧은 시간에 걸친 시험결과는 저온에서의 장시간에 걸친 시험 결과와 같다'라는 것이다. 따라서 여러 가지 서로 다른 고온에서 얻은 곡선은 실험적으로 결정되는 이동인자(shift factor, $a_{T}$ )에 의해 기준온도로 이동하게 되면 master curve가 작성된다. 이동인자 $a_{T}$ 는 기준온도에서의 물성변화에 대한 사용온도에서의 변화에 대한 시간비로 나타내며 Arrhenius 식의 형태를 따를 경 우 다음과 같이 쓸 수 있다.

$$
a_{T}=\exp \left[\frac{E_{a}}{R}\left(\frac{1}{T}-\frac{1}{T_{0}}\right)\right]
$$

따라서 master curve를 작성하는 데 필요한 $a_{T}$ 를 실험 적으로 구하면 이의 로그 플롯에 의해 활성화에너지 $E_{a}$ 를 구할 수 있고 식(1)로부터 시간-온도의 관계식을 구할 수 있다. 일반적으로 $a_{T}$ 는 온도가 높아질수록 지수적으 로 감소하는 경향이 있으므로 이 방법을 사용할 경우에 는 실험온도 범위에서 직선성을 보이면 열화기구의 변화 가 없는 것으로 생각된다.

그림 6 은 기준온도를 $200^{\circ} \mathrm{C}$ 로 할 때, 그림 4의 데이터 로부터 TTSP를 이용하여 작성한 master curve이다. 실험 적으로 구한 이동인자를 적용할 경우 $\log \mathrm{t}=\log a_{T}+\log$ $\mathrm{t}_{\mathrm{o}}$ 가 되므로 기준온도의 시간에 대하여 이동인자 만큼 이동하면 서로 다른 온도의 모든 데이터들이 시간축을 
조정한 한 개의 곡선으로 통일됨을 보여 준다. 이로부터 실제로는 수 십시간에 이르는 긴 실험을 거치지 않고도 장시간에 걸친 무게감량선의 변화를 예측할 수 있다. 한 편 그림 7은 이동인자 $a_{T}$ 의 Arrhenius plot을 보여주고 있다. 실험온도의 구간에서는 직선식에 잘 맞고 있으므로 따라서 $200 \sim 280^{\circ} \mathrm{C}$ 구간에서의 후가교 과정은 직선의 기 울기로부터 계산되는 활성화에너지 $108.25 \mathrm{~kJ} / \mathrm{mol}$ 을 가지 는 한 가지 메커니즘에 의해 진행된다고 말 할 수 있다. 그러나 이러한 고온촉진실험의 저온으로의 외삽에 의한 예측은 활성화에너지가 변하지 않는다는 전제하에 이루 어지는 것이므로 응용에 있어서는 상당한 주의가 요구된 다[11,12].

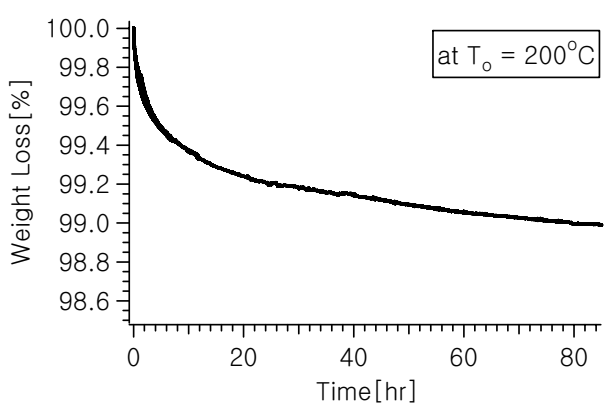

[그림 6] 기준온도 $200^{\circ} \mathrm{C}$ 에서의 마스터곡선

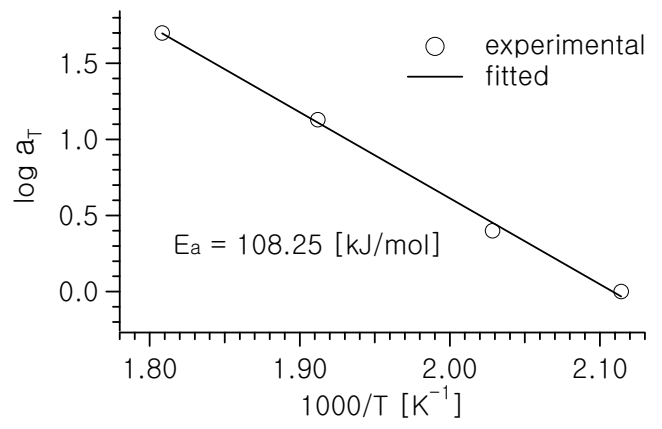

[그림 7] 이동인자 $a_{T}$ 의 Arrhenius plot

\section{4. 결 론}

$\mathrm{LCD}$ 백라이트 램프 홀더에 사용되는 실리콘 고무제 품의 TGA 열분석을 이용하여 1 차 및 2 차의 가교공정을 거친 완제품과 1 차 가교공정만 거친 시료 샘플의 각각에 대하여 서로 다른 몇 가지 온도에서의 등온 후가교 특성 을 연구한 결과 다음의 결과를 얻을 수 있었다.

1) 실리콘 고무로 만들어 지는 LCD 램프 홀더용 재료
는 사용되는 램프의 전극부위 어셈블리 구조와 실 제 동작온도 및 사용 환경에서 발생되는 불량 유발 과 관련지어 생각할 때, 1 차가교 성형 후에 반드시 2차적인 후가교 공정을 거쳐야만 휘발성 저분자합 물의 휘발에 의한 불량 유발을 방지할 수 있다.

2) LCD 램프홀더용의 실리콘 재료에 대해서는 휘발성 물질의 배출에 의한 중량감소가 처음 시작되는 온 도 $\mathrm{T}_{\mathrm{i}}$ 가 매우 중요하며 이온도는 실제 사용온도 보 다 훨씬 높아야 한다.

3) 후가교 시에는 반드시 환기를 해 주어야만 휘발 물 질의 entrapping에 의한 해중합 유발 등의 역효과를 방지할 수 있다.

4) 2 차 후가교 시의 휘발성 저분자화합물은 초기 20 30분 사이에 지수적으로 급격하게 감소하며 그 이후에는 약 $0.034 \mathrm{wt} \% / \mathrm{hr}$ 로서 일정한 속도로 계 속하여 서서히 무게감량이 진행되는 이중모드로 진행된다. 그러나 $250^{\circ} \mathrm{C}$ 이상의 온도에서는 열화 의 진행속도가 촉진된다.

5) 실제 적용되고 있는 LCD 램프홀더 재료의 동작온 도 환경을 고려할 때, $250^{\circ} \mathrm{C}, 2$ 시간의 후가교 조건 은 적절한 것으로 생각된다.

6) 시간-온도 중첩원리와 실험적으로 결정된 이동인자 값을 적용하여 기준온도 $200^{\circ} \mathrm{C}$ 에서의 master curve 를 작성할 수 있었으며, 이동인자는 실험온도구간 에서 Arrhenius식을 잘 만족함을 보여 주었으며 이 로부터 후가교 과정은 활성화에너지 $108.25 \mathrm{~kJ} / \mathrm{mol}$ 의 값을 가지는 단일 메커니즘으로 진행됨을 알 수 있었다.

\section{참고문헌}

[1] Noll, W., Chemistry and Technology of Silicons, 2nd ed., Academic Press, N. Y., pp. 305-309, 1968.

[2] Butts, M. et al, "Silicones", Encyclopedia of Polymer Science and Technology, 3rd ed. edited by Mark, H. F., John Wiley \& Sons, Inc., vol. 11, pp. 765-841, 2004.

[3] 정효성, 여학규, "Silicone Rubber의 가교특성”, 고무기 술, 제 1 권 제 1 호, pp. 103-113, 2000.

[4] 황장원, "실리콘 고무의 특성과 응용", 고무기술, 제8권 제2호, pp. 108-115, 2007.

[5] 황선일,"실리콘 고무의 개발동향", 산업연구원 신기술 동향, 제4권 제11호, pp. 20-27, 1990.

[6] Hatakeyama, T., Liu Z., "Thermal Analysis of Silicone Rubber", Handbook of Thermal Analysis, John Wiley \& Sons, pp. 126-128, 1998. 
[7] Caprino, J. C., Macander, R. F., "Silicone Rubber", Rubber Technology, 3rd ed., edited by Morton, M., Van Nostrand Reinhold Co., N. Y., pp. 375-409, 1987.

[8] Loganathan, K. S., "Synthetic Rubbers", Rubber Engineering, McGraw-Hill, New Delhi, pp. 445-512, 2000.

[9] Aron Technical Report, "Outgassing of Silicone Heater Compounds", http://www.arlon-std.com., 2004

[10] Rothka, J., Studd, R., Tate, K. and Timpe, D., "Outgassing of Silicone Elastomers", http://www.arlon-std.com,, 2002.

[11] Patel, M., Skinner, A. R., "Thermal ageing studies on room-temperature vulcanized polysiloxane rubbers", Polym. Degrd. Stab., Vol. 73, pp. 399-402, 2001.

[12] Patel, M., Soames, M., Skinner, A. R., Stephens, T. S., "Stress relaxation and thermogravimetric studies on room temperature vulcanized polysiloxane rubbers", Polym. Degrd. Stab., Vol. 83, pp. 111-116. 2004.

\section{안 원 술(WonSool Ahn)}

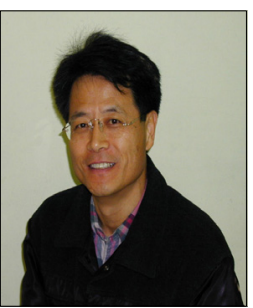

- 1979년 2월 : 서울대학교 화학공 학과(공학사)

- 1981년 2월 : 서울대학교 화학공 학과(공학석사)

- 1992년 8월 : KAIST 화학공학 과(공학박사)

- 1995년 3월 현재 : 계명대학 교 화학공학과 교수

<관심분야>

고분자 기능화, 고분자복합재료, 고무재료 등

이 준 만(JoonMan Lee)

[정회원]

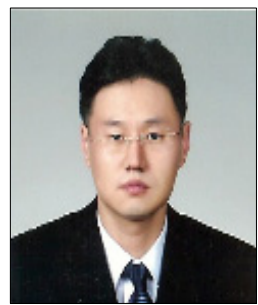

- 2004년 8월 : 계명대학교 화학공 학과(공학박사)

- 2007년 3월 : 나고야공대 화학공 학과(PostDoc)

- 2007년 3월 현재 : 계명대학 교 산업기술연구소 선임연구원

<관심분야>

분리공정, 고분자복합재료, 고무재료 등 